\title{
Comparative morphology on leaves of Daphniphyllum (Daphniphyllaceae)
}

\author{
M.-S. Tang ${ }^{1,2}$, Y.-P. Yang ${ }^{1}$, C.-R. Sheue ${ }^{3}$
}

Key words

Daphniphyllaceae

Daphniphyllum

epidermis

leaf anatomy

Lunata

stomata

\begin{abstract}
A comparative anatomical study on the leaves of nine out of 29 species of the genus Daphniphyllum was performed to seek support for the present infrageneric classification. Daphniphyllum is composed of two sections, Lunata (with one subsection Lunata) and Daphniphyllum (with two subsections, Daphniphyllum and Staminodia). The glabrous leaves with brachyparacytic stomata appear in all species in this study; hemiparacytic, laterocytic or anomocytic stomata occur in some taxa. Two (out of three) species of section Lunata show irregular epidermal cells with undulate anticlinal walls on both surfaces and hemiparacytic stomata. Of section Daphniphyllum seven (out of 26) species were sampled; they have curved, straight or undulate anticlinal cell walls and laterocytic or anomocytic stomata. The anatomical features found in this study are useful for identification on the specific level, but there is no support for the current infrasectional classification of section Daphniphyllum; further study on section Daphniphyllum is necessary.
\end{abstract}

Published on 30 October 2009

\section{INTRODUCTION}

Daphniphyllaceae is a monogeneric family distributed from tropical to subtropical Asia, including East Asia, Southeast Asia, Nepal, India, and Sri Lanka between about $46^{\circ} \mathrm{N}$ and $10^{\circ} \mathrm{S}$ and $75^{\circ} \mathrm{E}$ and $150^{\circ} \mathrm{E}$ (Rosenthal 1919, Huang 1965, 1966, 1996, 1997). Daphniphyllum comprises about 30 species (Ming 1980, Ming \& Kubitzki 2008) of evergreen trees or shrubs with simple, entire, alternate to subverticillate leaves. This genus was established by Blume (1826). The monographic study of Daphniphyllum was initiated by Müller in 1869, who distinguished 13 species. Rosenthal $(1916,1919)$ finished a monograph of Daphniphyllum with 24 recognized species and he divided the genus into two groups based on the presence/ absence of papillae on the abaxial leaf surface. Around fifty years later, Huang $(1965,1966)$ produced a second monograph of Daphniphyllum. He recognized nine species with 21 subspecies and around 25 varieties based on morphological characters of styles and sepals. Huang classified this genus into three sections: Lunata (3 species), Staminodia (2 species) and Daphniphyllum (4 species); and sect. Daphniphyllum was further subdivided into three subsections, Longicalycifera (1 species), Unicalycifera (2 species) and Daphniphyllum (1 species). However, 30 years later, Huang $(1996,1997)$ modified his classification and divided the genus into two sections, Lunata and Daphniphyllum, and he treated previous sect. Staminodia as a subsection of sect. Daphniphyllum. He also reduced previous subsections, Longicalycifera and Unicalycifera, to series under subsect. Daphniphyllum (Huang 1996, 1997) (Fig. 1).

Textures and shapes of the leaves are variable in Daphniphyllum (Croizat \& Metcalf 1941, Huang 1965). The staminate flowers and drupes only provided limited characters for species identification, also in combination with leaf morphology (Huang 1965). Leaf anatomical features proved to be of great

\footnotetext{
Department of Biological Sciences, National Sun Yat-sen University, 70 Lien-hai Rd., Kaohsiung 804, Taiwan.

2 Department of Food Nutrition, Chung Hwa University of Medical Technology, 89 Wunhwa 1st St., Rende Township, Tainan 717, Taiwan.

${ }^{3}$ Department of Biological Resources, National Chiayi University, 300 Syuefu $\mathrm{Rd}$, Chiayi 600, Taiwan.
}

value in many taxa not only in identifying species, but also in understanding relationships between taxa (Baas 1981, Pan et al. 1990, Mentink \& Baas 1992, Kong 2001, Sheue et al. 2003, Gonzalez et al. 2004, Kocsis et al. 2004, Carpenter $2005,2006)$. The leaf anatomical study of Daphniphyllum was extremely meager up to now. Metcalfe \& Chalk $(1988,1989)$ described paracytic stomata, clusters of crystals and papillae on the abaxial surface for Daphniphyllum. The stomatal complex of four species of Daphniphyllum, D. chartaceum, D. macropodum, $D$. triangulatum and $D$. yunnanense, was studied by Zhang \& Lu (1989). They showed that the paracytic type occurs in all four species. Huang (1965) described the leaf anatomy for five taxa, $D$. calycinum, $D$. gracile, $D$. glaucescens subsp. oldhamii, $D$. himalaense subsp. angustifolium and $D$. himalaense subsp. macropodum, and mentioned that "the upper, lower epidermis, sponge and palisade cells are different within species level".

The purpose of this comparative study is to provide morphological and anatomical characters, which may be helpful in species identification and can be used to support the present classification of the genus.

\section{MATERIALS AND METHODS}

Of the 29 Daphniphyllum species, two (out of three) species, $D$. calycinum and $D$. majus, were sampled to represent sect. Lunata; the other seven species (out of 26) were selected to represent sect. Daphniphyllum (Table 1). For two species dried leaf fragments of herbarium specimens were used. Fresh and desiccated materials of the other species were collected in the field in China, Japan, the Philippines and Taiwan. Vouchers are deposited in the herbarium of SYSU.

Fresh leaf pieces were fixed in FPGA (formalin : propionic acid : glycerol : $95 \%$ ethanol : distilled water $=5: 5: 15: 35: 40$ in volume). Desiccated material was dipped in water and then transferred to FPGA. Parts of leaf samples were dehydrated by ethanol series and then embedded in paraffin for microtome section. Sections of 8-12 $\mu \mathrm{m}$ thickness were cut by a Leitz 1512 rotary microtome and stained with $1 \%$ Safranin $O$ and $0.5 \%$ fast green. The apex, middle and base parts of leaves

(๑) 2009 Nationaal Herbarium Nederland

You are free to share - to copy, distribute and transmit the work, under the following conditions:

Attribution: $\quad$ You must attribute the work in the manner specified by the author or licensor (but not in any way that suggests that they endorse you or your use of the work).

Non-commercia:

You may not use this work for commercial purposes.

No derivative works: You may not alter, transform, or build upon this work.

For any reuse or distribution, you must make clear to others the license terms of this work, which can be found at http://creativecommons.org/licenses/by-nc-nd/3.0/legalcode. Any of the above conditions can be waived if you get permission from the copyright holder. Nothing in this license impairs or restricts the author's moral rights. 


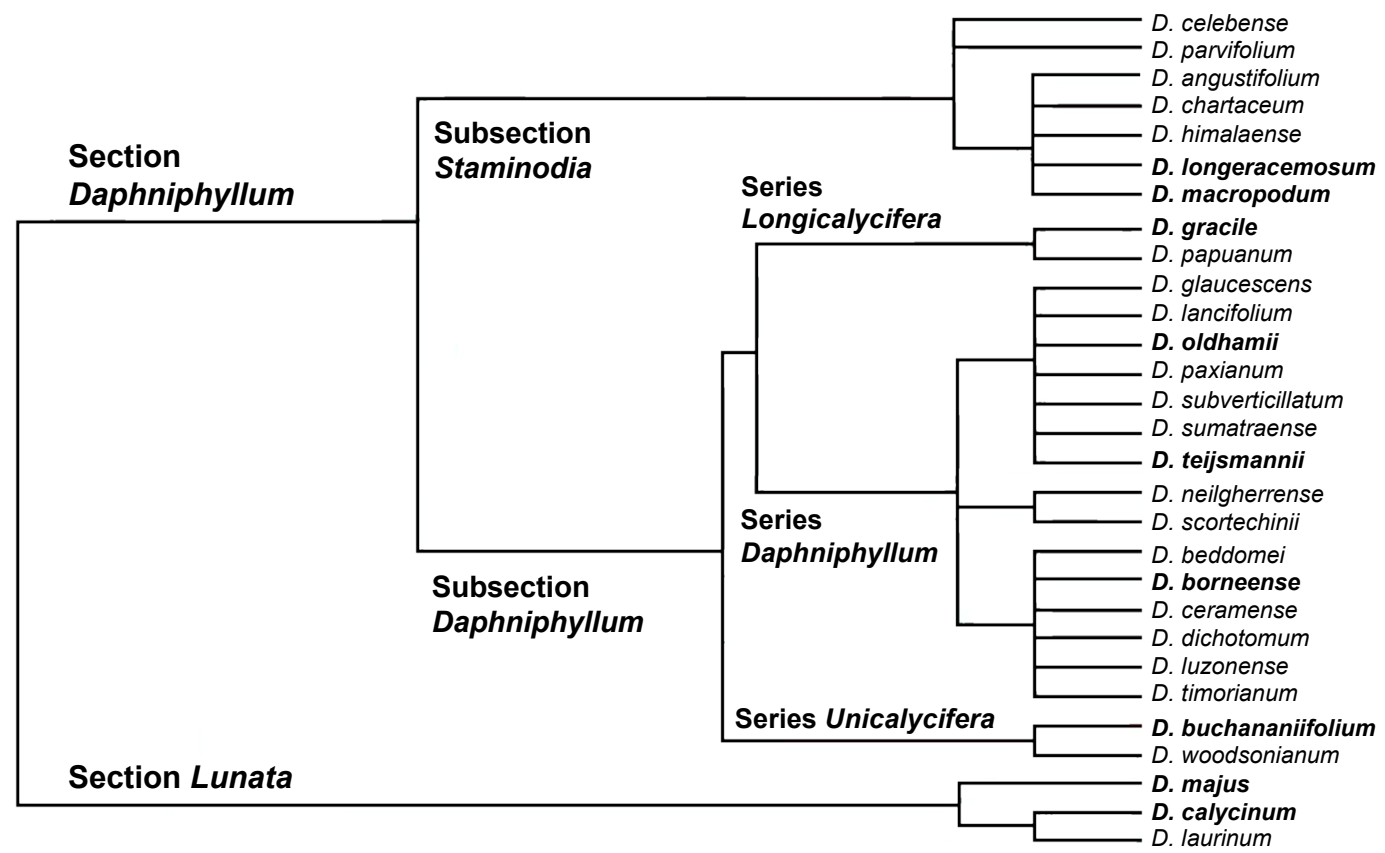

Fig. 1 Diagram showing the classification of Daphniphyllum based on Huang (1965, 1996, 1997), Ming \& Kubitzki (2008) and Hatusima (1971). Studied species are indicated in bold.

were cleared with $3 \%$ sodium hydroxide at $40{ }^{\circ} \mathrm{C}$ for $5-14$ days and stained with $1 \%$ Safranin $O$. Paraffin sections and cleared leaves were observed and photographed with a Leica DME light microscope and a Nikon D70s digital camera. The mean length of stomatal guard cells was measured from each specimen with 40 replications.

Terminology follows Dilcher (1974) except for the term 'laterocytic stomata' (Carpenter 2005) that was used to describe the unequal parts of asymmetric stomata.

\section{RESULTS}

Leaf characteristics of the epidermis and transverse sections of Daphniphyllum are summarized in Table 2. Palisade tissue, stomatal and epidermal features of all studied taxa appear to be constant on the species level. Typical leaf morphological characters for sections, subsections and series are summarized in Table 3.

\section{Palisade and spongy tissues}

The leaf structure of Daphniphyllum is dorsiventral. The nine species can be divided into two groups on the basis of cell form and arrangement of palisade tissues (Table 2). One group shows columnar and compactly arranged palisade cells (Fig. $2 c, f-h)$. The other group shows loosely arranged conical to round palisade cells (Fig. 2a, b, d, e). The first group comprises species in subsect. Daphniphyllum (D. borneense, $D$. buchananiifolium, $D$. gracile, $D$. oldhamii and $D$. teijsmannii); the second group contains sect. Lunata ( $D$. calycinum, D. majus) and subsect. Staminodia (D. longeracemosum and $D$. macropodum). The palisade cells are 1-layered in most species of the second group except for $D$. macropodum with three layers.

Table 1 Leaf materials of Daphniphyllum used in this study. The classification follows Huang (1996, 1997), Ming \& Kubitzki (2008) and Hatusima (1971).

\begin{tabular}{|c|c|c|c|c|c|}
\hline Classification & Taxon & Collector and specimen no. & Material state & Location & Herbarium \\
\hline \multirow[t]{5}{*}{ Sect. Lunata } & D. calycinum & S.H. Yen T0957 & Fresh & Botanical garden in Hung Kong & SYSU \\
\hline & D. calycinum & L.C. Shih T1224 & Fresh & Hung Kong & SYSU \\
\hline & D. majus & S.H. Yen T1195 & Fresh & Yunnan, China & SYSU \\
\hline & D. majus & Y.M. Ho T1189 & Fresh & Mt Da-wei, Bing-bian, Yunnan, China & SYSU \\
\hline & D. majus & T. Sørensen et al. 3090 & Dried & Chiengmai, Doi Sutep, Thailand & L \\
\hline \multicolumn{6}{|l|}{ Sect. Daphniphyllum } \\
\hline \multirow[t]{6}{*}{ Subsect. Staminodia } & D. longeracemosum & M.S. Tang \& Y.M. Ho T1165 & Fresh & Mt Da-wei, Bing-bian, Yunnan, China & SYSU \\
\hline & D. longeracemosum & M.S. Tang T1179 & Fresh & Fa-dou, Xi-chou, Yunnan, China & SYSU \\
\hline & D. macropodum & M.S. Tang et al. T1202 & Fresh & Tsukuba Botanical Garden, Japan & SYSU \\
\hline & D. macropodum & M.S. Tang T1246 & Fresh & Xiang-yang, Taidong, Taiwan & SYSU \\
\hline & D. macropodum & M.S. Tang et al. T1259 & Fresh & Wan-rong Forest Road, Hualien, Taiwan & SYSU \\
\hline & D. macropodum & M.S. Tang T1270 & Fresh & Mt Lan-qian, Ilan, Taiwan & SYSU \\
\hline \multicolumn{6}{|l|}{ Subsect. Daphniphyllum } \\
\hline \multirow[t]{6}{*}{ Ser. Daphniphyllum } & D. borneense & P. van Royen 7867 & Dried & Mt Kinabalu, Sabah, Malaysia & L \\
\hline & D. borneense & J.M.B. Smith 476 & Dried & Mt Kinabalu, Sabah, Malaysia & L \\
\hline & D. oldhamii & M.S. Tang T0698 & Fresh & Da-zhi, Taipei, Taiwan & SYSU \\
\hline & D. oldhamii & M.S. Tang T1136 & Fresh & Mt Xian, Miaoli, Taiwan & SYSU \\
\hline & D. teijsmannii & L.C. Shih T1193 & Fresh & Okinawa, Japan & SYSU \\
\hline & D. teijsmannii & M.S. Tang et al. T1207 & Fresh & Tsukuba Botanical Garden, Japan & SYSU \\
\hline \multirow[t]{2}{*}{ Ser. Unicalycifera } & D. buchananiifolium & M.S. Tang T0917 & Dried & Baguio, Luzon, the Philippines & SYSU \\
\hline & D. buchananiifolium & M.S. Tang T0920 & Dried & Baguio, Luzon, the Philippines & SYSU \\
\hline Ser. Longicalycifera & D. gracile & M.J Wu et al. LAE 88822 & Dried & Keglsugl, Papua New Guinea & LAE \\
\hline
\end{tabular}




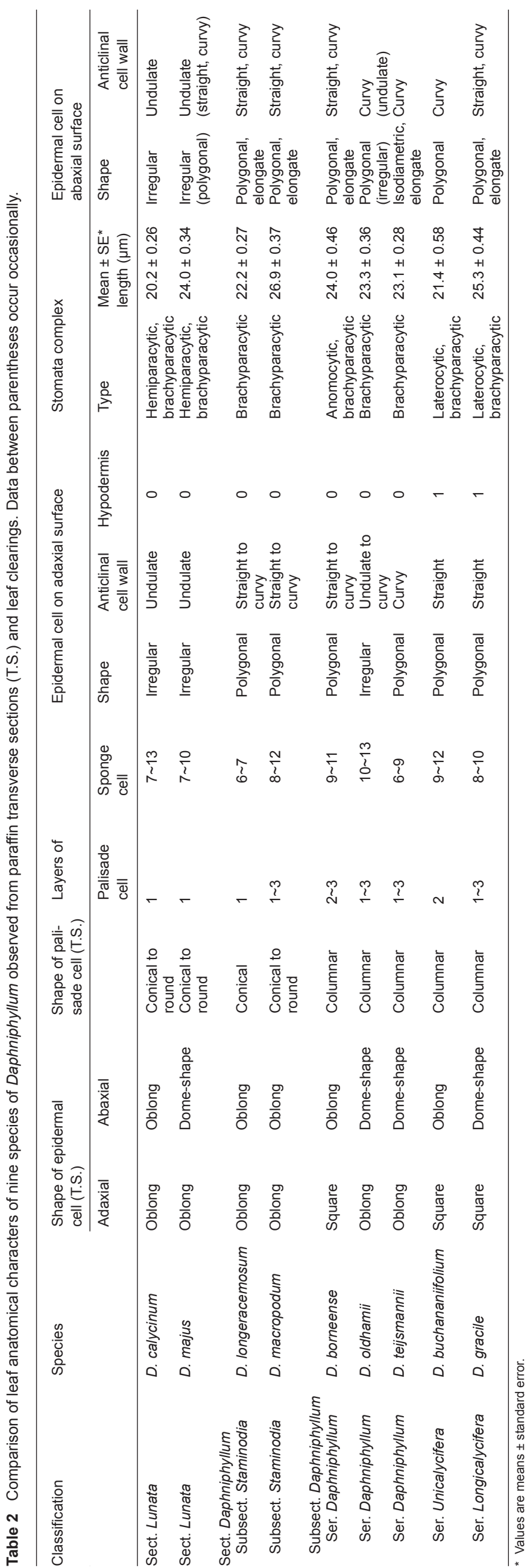

Table 3 The typical leaf morphological characters for sections, subsections and series of Daphniphyllum observed in this study.

\begin{tabular}{|c|c|}
\hline Taxon & Typical character \\
\hline Sect. Lunata & $\begin{array}{l}\text { Hemiparacytic stomata } \\
\text { Irregular epidermal cells in shape on both sur- } \\
\text { faces } \\
\text { Undulate anticlinal cell walls on both surfaces }\end{array}$ \\
\hline \multicolumn{2}{|l|}{ Sect. Daphniphyllum } \\
\hline Subsect. Staminodia & Conical to round palisade cells \\
\hline Subsect. Daphniphyllum & Columnar palisade cells \\
\hline Ser. Daphniphyllum & No hypodermis \\
\hline $\begin{array}{l}\text { Ser. Longicalycifera \& } \\
\text { Unicalycifera }\end{array}$ & Laterocytic stomata and 1-layered hypodermis \\
\hline
\end{tabular}

\section{Epidermal cells}

The adaxial epidermal cells show in transverse section two types of cellular shapes, square or oblong (Table 2). Square adaxial epidermal cells occur in D. buchananiifolium (Fig. 2c), $D$. borneense (Fig. 2g) and D. gracile of subsect. Daphniphyllum, and oblong epidermal cells appear in all the other species of both sect. Daphniphyllum and sect. Lunata.

The anticlinal walls on both surfaces of the epidermal cells of Daphniphyllum are straight, curved or undulate (Fig. 3). The type of anticlinal cell walls is constant on the species level, but varies between the species (Table 2). The two species of sect. Lunata show undulate anticlinal walls on both leaf surfaces (Fig. $3 a-c)$. The anticlinal cell walls on both surfaces are straight, straight to curved or curved in all studied species of sect. Daphniphyllum except somewhat undulate in D. oldhamii (Fig. 3l).

The epidermal cells are polygonal, irregular, elongate and isodiametric in shape on both surfaces (Fig. 3, Table 2). Three species, D. calycinum, D. majus (both sect. Lunata) (Fig. 3c) and D. oldhamii (sect. Daphniphyllum) (Fig. 3I), have irregular epidermal cells on the adaxial side only, while the other species of sect. Daphniphyllum have polygonal adaxial epidermis (Fig. $3 e, f, i$, Table 2). Four epidermal shapes could be distinguished abaxially; seven species always show two shapes and only two species have a single type. The isodiametric shape is found only in leaves of $D$. teijsmannii (Fig. $3 \mathrm{j}$ ) and restricted to the abaxial surface.

\section{Hypodermis}

A single layer of adaxial hypodermal cells (Table 2) is present in only two species, D. buchananiifolium (Fig. 2c) (subsect. Daphniphyllum ser. Unicalycifera) and D. gracile (Fig. 2f) (subsect. Daphniphyllum ser. Longicalycifera).

\section{Stomata types}

The stomata are restricted to the abaxial leaf surface only and randomly distributed. Four types of stomata are found, i.e. anomocytic, brachyparacytic, laterocytic and hemiparacytic (Table 2). The most common type is brachyparacytic, which is present in all nine taxa (Fig. 3a, b, d, g, h, j, k). The present study revealed three additional types of stomata in five species. The laterocytic type is present in $D$. gracile (ser. Longicalycifera) (Fig. 3g) and D. buchananiifolium (ser. Unicalycifera) (Fig. 3h); the hemiparacytic type is found in $D$. calycinum and $D$. majus (Fig. 3b) (sect. Lunata) and the anomocytic type in $D$. borneense (sect. Daphniphyllum).

The mean length of the guard cells varies between 20.2-26.9 $\mu \mathrm{m}$ (Table 2). Daphniphyllum macropodum has the longest guard cells and $D$. calycinum has the shortest ones.

We summarized the typical leaf morphological characters for different taxa in Table 3. First, hemiparacytic stomata, irregular epidermal cells and undulate anticlinal cells on two sides 

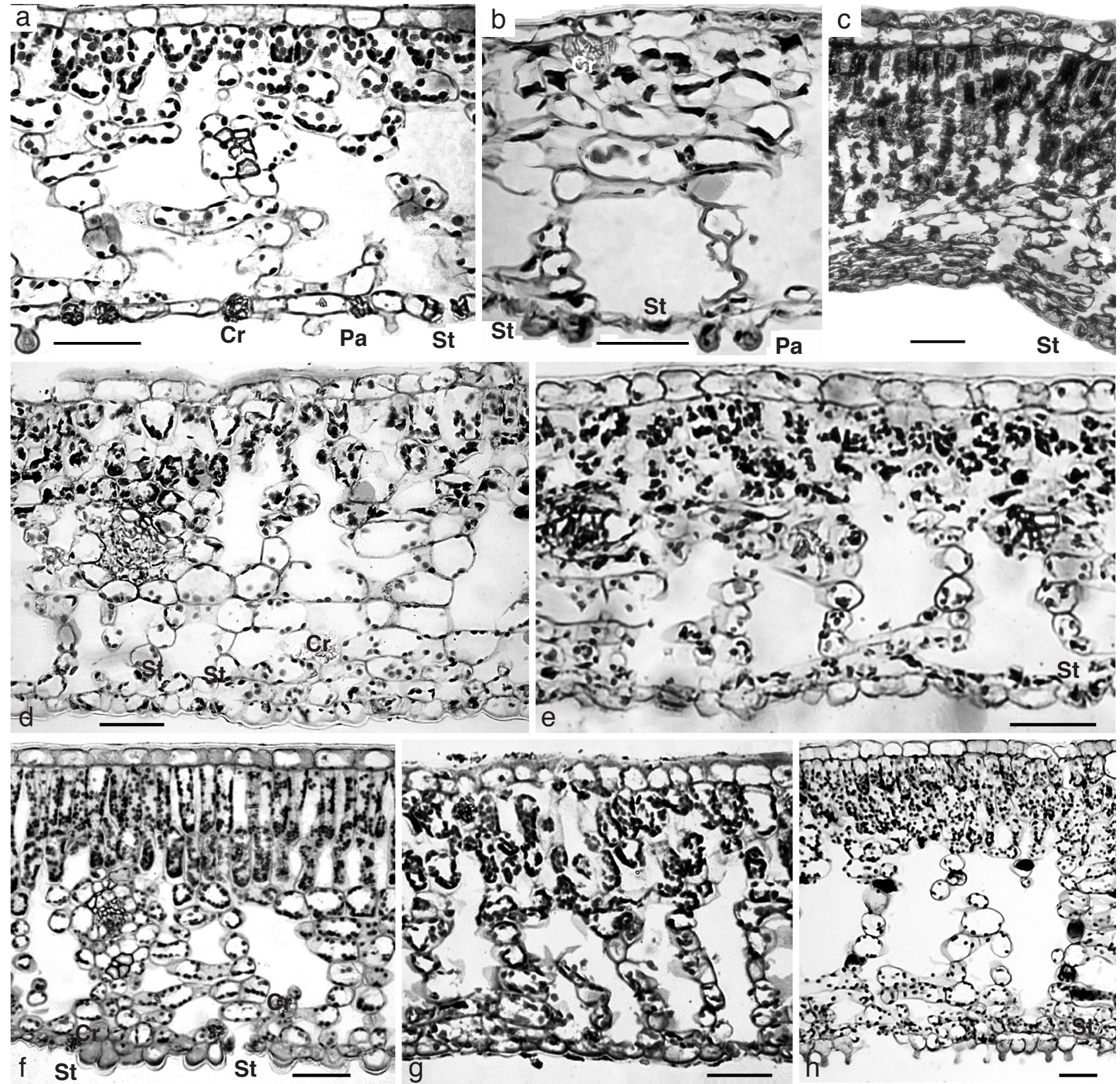

Fig. 2 Light microscopy photographs of transverse leaf sections of Daphniphyllum species. a, b. Sect. Lunata; c, f-j. subsect. Daphniphyllum; d, e. subsect. Staminodia. - a. D. calycinum; b. D. majus; c. D. buchananiifolium; d. D. macropodum; e. D. longeracemosum; f. D. teijsmannii; g. D. borneense; h. D. oldhamii. - Abbreviations: $\mathrm{Cr}=$ crystal; $\mathrm{Pa}=$ Papillae; $\mathrm{St}=$ stomata complex. - Scale bars $=50 \mu \mathrm{m}$.

are characteristic for sect. Lunata. Secondly, the outstanding character typical for subsect. Staminodia and Daphniphyllum of sect. Daphniphyllum is the shape of the palisade cells (conical to round vs columnar). Finally, we also can distinguish ser. Longicalycifera and Unicalycifera from subsect. Daphniphyllum based on laterocytic stomata and a 1-layered hypodermis, but there is no other available character to further differentiate both series. The characters mentioned above may serve as remarkable taxonomic characteristics for the genus Daphniphyllum.

\section{DISCUSSION}

Huang (1965) reported that the genus Daphniphyllum shows two distinct types of mesophyll tissue, i.e. well differentiated palisade and spongy layers and poorly differentiated palisade and spongy layers. This is confirmed by our study. Huang (1965) also indicated that $D$. angustifolium (sect. Daphniphyllum subsect. Staminodia) possesses a well-differentiated mesophyll and an adaxial hypodermis. However, the specimens of the two investigated species (D. macropodum and $D$. longeracemosum) of the same subsection did not reveal Huang's characters at all. Moreover, these features "well differentiated mesophyll tissue and adaxial hypodermis" as Huang found for D. angustifolium (subsect. Staminodia) were only found in two of the five species of subsect. Daphniphyllum in this study. Based on these results, we assume that a relatively close relationship may occur between $D$. angustifolium and subsect. Daphniphyllum.

Four types of stomata are found, i.e. brachyparacytic, hemiparacytic, laterocytic and anomocytic; the latter two types are first reported here. These distinctive stomatal types can be important characters for an infrageneric classification. Paracytic stomata were the only type reported for Daphniphyllum so far (Huang 1965, Metcalfe \& Chalk 1988, Zhang \& Lu 1989). However, the brachyparacytic type may just be a more specific term than the one used in any of the earlier articles (Huang 1965 in Fig. 3, Zhang \& Lu 1989 in Plate 1). Furthermore, laterocytic stomata are first reported here, but we notice that they were already visible for $D$. gracile in Huang (1965: f. 3). Anomocytic stomata 

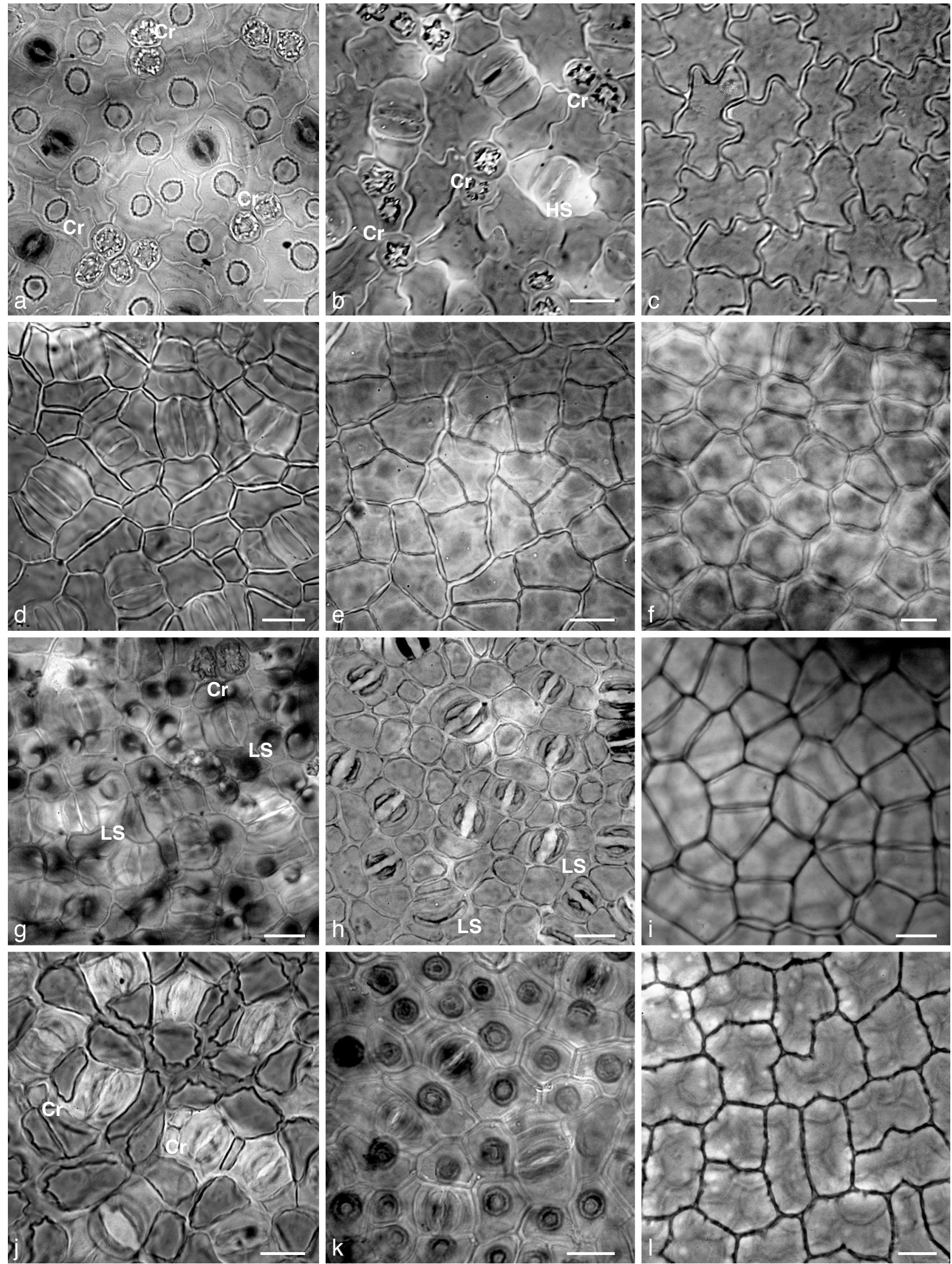

Fig. 3 Light microscopy photographs of the leaf epidermis of Daphniphyllum species. a, b, d, g, h, j, k. Abaxial view; c, e, f, i, I. adaxial view. a. D. calycinum; b, c. D. majus; d, e. D. macropodum; f. D. borneense; g. D. gracile; h, i. D. buchananiifolium; j. D. teijsmannii; k, I. D. oldhamii. $-\mathrm{Abbreviations:} \mathrm{Cr}=\mathrm{crystal}$; $\mathrm{HS}=$ hemiparacytic stomata; $\mathrm{LS}=$ laterocytic stomata. - Scale bars $=20 \mu \mathrm{m}$ 
only occur in $D$. borneense. The hemiparacytic stomatal type exclusively occurs in sect. Lunata, while the laterocytic stomata only appear in ser. Longicalycifera and Unicalycifera of subsect. Daphniphyllum.

Huang $(1996,1997)$ treated D. gracile (ser. Longicalycifera) and $D$. buchananiifolium (ser. Unicalycifera) in different series. However, the anatomical characters like hypodermis, straight anticlinal adaxial cell walls and laterocytic stomata may point to a closer relationship between these species. The various ranges of stomatal types may be an aid to recognize the different infrageneric taxa within the Daphniphyllaceae.

Within the nine studied species, D. oldhamii and $D$. teijsmannii are similar in morphological character. Huang (1966) distinguished them by papillose/epapillose on the abaxial surface of leaves. However, Huang (1965) and Wang (1981) mentioned that the character of papillae is unstable in $D$. oldhamii, so that identification of the two species is difficult. Our results show distinguishing differences in the epidermis. Daphniphyllum oldhamii has undulate and irregular adaxial epidermal cells, while $D$. teijsmannii not only shows straight and curved anticlinal cells on the adaxial surface but it also has isodiametric abaxial epidermal cells. Other studied species of the series can also be distinguished by two characters, shape of epidermal and size of guard cells (Table 2). For example, D. calycinum and $D$. majus of sect. Lunata can be distinguished by the characters oblong abaxial epidermis/smaller $(20.2 \mu \mathrm{m})$ guard cells vs dome-shape abaxial epidermis/bigger $(24.0 \mu \mathrm{m})$ guard cells. Due to the overlap of anatomical characters among the species of subsect. Staminodia, and between the species of ser. Longicalycifera and Unicalycifera, the size of guard cells is the only one character to support the classification.

The undulate anticlinal cell walls of both epidermal layers, the irregular epidermal cells of upper and lower surfaces, and the hemiparacytic stomata are typical characters of sect. Lunata. Anatomically, these three characters may well support the theory that sect. Lunata is likely to be a natural group. However, the leaf anatomical characters within sect. Daphniphyllum are highly divergent, which may imply that the current infrasectional classification is artificial. Furthermore, Huang (1965) pointed out that the two sections Staminodia (currently subsect. Staminodia of sect. Daphniphyllum) and Calycifera (currently subsect. Daphniphyllum) are artificial sections. The limited samples of sect. Daphniphyllum in this study may be inadequate to draw firm conclusions for classification of sect. Daphniphyllum. Therefore, more comprehensive studies on sect. Daphniphyllum are still warranted.

Acknowledgements The authors deeply thank Dr. Peter C. van Welzen for improving the manuscript, Dr. Tseng-Chieng Huang for providing valuable suggestions, the curators of the herbaria HAST, L, TAIF, TNM for providing leaf samples. We are indebted to Ms. Tutie Djarwaningsih (Indonesia), Dr. Jean W.H. Yong (Singapore), Dr. Teodora M. Balangcod, Mr. Roland Hipol (the Philippines), Mr. Ce-hong Li, Mr. Yongming He, Dr. Zhao-Rong He (China), Mr. Yu Ito, Dr. Norio Tanaka (Japan), Dr. Ming-Jou Wu, Dr. Shenhorn Yen and Mr. Li-cheng Shih (Taiwan), who contributed or helped to collect plant materials. The project was supported by the National Science Council, Taiwan (grant NSC 95-2621-B-110-002).

\section{REFERENCES}

Baas P. 1981. A note on stomatal types and crystals in the leaves of Melastomataceae. Blumea 27: 475-479.

Blume CL. 1826. Bijdragen tot de Flora van Nederlandsch Indië 17: 11521153. Lands Drukkerij, Batavia.

Carpenter KJ. 2005. Stomatal architecture and evolution in basal angiosperms. American Journal of Botany 92: 1595-1615.

Carpenter KJ. 2006. Specialized structures in the leaf epidermis of basal angiosperms: morphology, distribution, and homology. American Journal of Botany 95: 665-681.

Croizat L, Metcalf FP. 1941. The Chinese and Japanese species of Daphniphyllum. Lingnan Science Journal 20: 105-130.

Dilcher DL. 1974. Approaches to the identification of angiosperm leaf remains. Botanical Review 40: 2-157.

Gonzalez CC, Gandolfo MA, Cuneo RN. 2004. Leaf architecture and epidermal characters of the Argentinean species of Proteaceae. International Journal of Plant Sciences 165: 521-536.

Hatusima S. 1971. Flora of the Ryukyus: 374. Okinawan Society of Biological Education and Research, Okinawa. (In Japanese.)

Huang TC. 1965. Monograph of Daphniphyllum I. Taiwania 11: 57-98.

Huang TC. 1966. Monograph of Daphniphyllum II. Taiwania 12: 137-234.

Huang TC. 1996. Notes on taxonomy and pollen of Malesian Daphniphyllum (Daphniphyllaceae). Blumea 41: 231-244.

Huang TC. 1997. Daphniphyllaceae. Flora Malesiana, Ser. I, Vol. 13: 145168.

Kocsis M, Darok J, Borhidi A. 2004. Comparative leaf anatomy and morphology of some neotropical Rondeletia (Rubiaceae) species. Plant Systematics and Evolution 248: 205-218.

Kong H. 2001. Comparative morphology of leaf epidermis in the Chloranthaceae. Botanical Journal of the Linnean Society 136: 279-294.

Mentink H, Baas P. 1992. Leaf anatomy of the Melastomataceae, Memecylaceae, and Crypteroniaceae. Blumea 37: 189-225.

Metcalfe CR, Chalk L. 1988. Anatomy of the Dicotyledons Vol. I. 2nd ed. Oxford University, New York.

Metcalfe CR, Chalk L. 1989. Anatomy of the Dicotyledons Vol. II. 2nd ed Oxford University, New York.

Ming TL. 1980. Daphniphyllaceae. In: Cheng M, Ming TL (eds), Flora Reipublicae Popularis Sinicae 45: 1-11. Science Press, Beijing. (In Chinese.)

Ming TL, Kubitzki K. 2008. Daphniphyllaceae. In: Wu ZY, Raven PH, Hong DY (eds), Preparation Flora of China 11. Science Press, Beijing and Missouri Botanical Garden Press, St. Louis. (Available at http://hua.huh. harvard.edu/china/mss/volume11/index.htm. Early-out version, visited on 2008/1/17.)

Müller JA. 1869. Daphniphyllaceae. In: De Candolle A(ed), Prodromus Systematis Naturalis Regni Vegetabilis 16: 1-6. Masson \& Filii, Parisiis.

Pan KY, Lu AM, Wen J. 1990. Characters of leaf epidermis in Hamamelidaceae. Acta Phytotaxonomica Sinica 28: 10-26.

Rosenthal K. 1916. Monographie der Gattung Daphniphyllum. Nischkowsky, Breslau.

Rosenthal K. 1919. Daphniphyllaceae. In: Engler A (ed), Das Pflanzenreich 68: 1-15. Engelmann, Leipzig.

Sheue CR, Liu HY, Yang YP. 2003. Morphology and anatomy on stipules and leaves of the mangrove genus Kandelia (Rhizophoraceae). Taiwania 48: $248-258$.

Wang JX. 1981. A revision of Daphniphyllaceae in China. Acta Phytotaxonomica Sinica 19: 69-84. (In Chinese.)

Zhang ZY, Lu AM. 1989. On the systematic position of Daphniphyllaceae. Acta Phytotaxonomica Sinica 27: 17-30. (In Chinese with English abstract.) 